\title{
VENGEFUL ANIMALS, INVOLUNTARY MOURNING, AND THE ETHICS OF NDYUKA AUTONOMY
}

\author{
STUART EARLE STRANGE \\ Yale-NUS College \\ (iD https:/ / orcid.org/0000-0002-1957-5387
}

This essay considers the connections among mourning, human autonomy, and interspecies responsibility. To do so, it turns to the involuntariness of mourning and the demands that grief makes on how relationships between humans and animals are witnessed. Starting from Judith Butler's $(2004,34)$ proposition that "if a life is not grievable, it is not quite a life," I focus on kunu (avenging spirits) who haunt Ndyuka Maroons inhabiting the Caribbean country of Suriname to ask what the spectral vengeance of animals reveals about grief and accountability. Relations with kunu, I argue, illustrate the ways in which nonhuman lives become grievable, but also how mourning reveals a Ndyuka ethics of autonomy, with important implications for what responsibility to others really means within an expansively relational reality defined by mortality.

As the links between mass extinction and plantation capitalism become ever more incontestable (Tsing 2012), it is a necessary anthropological task to examine how people like Ndyukas - themselves historic refugees from the plantation system - have fashioned ways of confronting nonhuman suffering and dying. Such an analysis, however, calls for a clear-eyed acknowledgment that other paradigms of responsibility to nonhumans are not without their own complex and telling contradictions. Nevertheless, how people are moved from their attempts to re- 
main ethically distinct from other life-forms to mourning discrete animal deaths remains a vital question amid our present global crisis of biodiversity. For many Ndyukas, recognizing this interdependence with other sentient beings marks the decisive first principle of human autonomy, and how it can be secured in a world saturated by death and exploitation.

\section{MOURNING, GRIEF, AND THE POLITICS OF DEATH}

Perhaps no other phenomenon of human life so insistently exposes the total and consuming intensity of our interdependence as mourning (Butler 2004; Briggs 2014; Mueggler 2017). As both the communicative expression of grief and the rituals that strive to confront and contain it (Freud 1957; Hertz 1960), mourning captures how every aspect of our existence is caught up in the lives of others such that we "live each other's lives and die each other's deaths" (Sahlins 2013, 28). When we mourn, we are taken over by the completeness of particular deaths and collapse into the finitude of shared lives that must go on despite the absence of precisely those who made this sharing meaningful. Whether stoic or hysterical, grief expands "ordinary understandings of the self and its possible social relations" (Dave 2014, 434), underscoring our irrevocable relationality with others.

Animal studies and multispecies ethnography have embraced mourning and grief to demonstrate yet another way in which affective sociality is widely shared (Weil 2012; Parreñas 2018). Elephants who return to the remains of fellows and crows who caw sorrowfully for deceased mates are just some of the subjects whose grief has been invoked to show humanity's unity with the rest of the animal world (King 2014; Van Dooren 2014). Because it scrubs away persistent anthropocentricism, acknowledging nonhuman grief enables humans to accept animal subjectivity and "mourn with" animals "for some of the many losses of life and diversity within our shared world" (Van Dooren 2014, 129) in a time of anthropogenic mass extinction.

This embrace of animal mourning indicates more than a belated realization of common emotional faculties. It is also a rather pointed riposte to how Euro-American thought has hoarded awareness of death for humans so as to limit accountability to other species. This attitude becomes apparent in everyday indifference to practices like industrial animal slaughter (Blanchette 2018) and forms part of a long history stemming from both Aristotelean philosophy and Christian theology of treating nonhuman animals as "outside the terms of moral reference" (Thomas 1983, 148). For twentieth-century philosophers like Martin Heidegger, humans could thus still be the only animals who "experience death as death" (quoted in 
Weil 2012, 101), while poets such as Rainer Maria Rilke (2000, 47) could describe animals as being "free from death." In this tradition animals are said to never respond to their mortality, only to react to it (Derrida 2008). Denied knowledge of their own deaths, animals are thereby condemned to exist outside the responsibilities to self and other that constitute the central existential drama of human life, shorn of relationality and rendered "killable" at the hands of uniquely self-aware humans (Thomas 1983; Haraway 2007, 105; Weil 2012).

The "killability" of animals has found further philosophical justification in dominant Euro-American assumptions that political authority entails both the right to put others to death and to erase any claims that those dead may have on the living (Foucault 1977; Derrida 1994). These assumptions permit modern states and property owners to sever all relations of responsibility to those killedwhether citizens, enemy combatants, or other species — when they are legally defined as either threats, possessions, or sustenance. Imagining the sovereign human/Euro-American subject as autonomous from any ethical obligation to animal and social others removes those so othered from social relations in a way that their abuse, suffering, and death need never be mourned (Wynter 1994; Kim 2015).

For Ndyukas who are pursued by the avenging spirits known as kunu, the above presuppositions are unthinkable. Animal kunu, the subject of this article, terrorize those to whom they attribute their unjust deaths, thereby forcing Ndyukas to recognize that humans are neither uniquely aware of death nor capable of exerting the "control over mortality" (Mbembe 2003, 12) at the heart of dominant Euro-American political-economic practice. As vengeful ghosts who return to witness their own tragic deaths and to compel those whom they hold responsible to mourn alongside them, kunu reveal that, because every death creates inescapable obligations, killing marks the beginning of relatedness for Ndyukas, rather than its end.

The forms of mourning and accountability created by death — whether human or nonhuman - are the basis of Ndyuka politics. For Ndyukas, the primary political concern is the descent group and the shared "social vulnerability" (Butler 2004, 22) to death that kinship imposes. Divided into matrilineages and clans, Ndyuka society embeds persons in large extended families and multiple generations of relatives, and people are seemingly forever in collective mourning for the recently deceased. Traditional Ndyuka political leaders derive their authority not from deciding who lives or dies but from managing relations with the dead through divination, complex funeral rites, and periods of ritual grieving that last many months (Thoden van Velzen and van Wetering 2004; Parris 2011). As curses 
that implicate an entire collectivity, kunu are central protagonists in lineage-wide "cults of affliction" (Turner 1981) that provide explanations for why people suffer and die when and how they do (Evans-Pritchard 1937). By tying every human death to the failure of the deceased's kin group to cooperatively mourn those they have wronged, kunu instigate the matrilineal solidarity that is the regnant principle of Ndyuka political kinship. Kunu thus expand relatedness beyond the kin group and compel Ndyukas to recognize their shared culpability for acts of violence committed by their relatives (Thoden van Velzen 1966; Price 1973; Strange 2018). This notion sutures the kin of human killers to the kin of those they kill, establishing relations of involuntary mourning with previously unconnected entities.

In a context in which almost every facet of sociality is inflected by mourning, autonomy - by which I mean the freedom to define one's own future relationships without interference-implies something different from the individual or national self-sovereignty emphasized in prevailing Euro-American thought. Because kunu enforce collective responsibility to others - including to other species - Ndyuka notions of autonomy are premised on the inescapability of accountability. To be autonomous means to know how to respectfully anticipate otherwise inseverable relations of mourning for those to whom no preexisting responsibility exists. Ndyuka autonomy derives from understanding that every death has repercussions that impose greater interconnectedness. Such autonomy is irreducibly relational, achieved by the preemptive acknowledgment that others have a right to exist where they are and on their own terms (Pires 2019). Failing to do so can only result in kunu forcing whole descent groups to involuntarily suffer and mourn with them.

As the historical epicenter of the colonial capitalist plantation complex, the Caribbean has been especially scarred by the "necropolitics" (Mbembe 2003) of European domination premised on animalizing racialized and enslaved Africans and Native Americans (Williams 1994; Brown 2008). As adroitly highlighted by Bénédicte Boisseron (2018), this history makes the Caribbean critical for understanding the intertwined development of human, animal, and ecological exploitation under white supremacy and plantation capitalism. It also makes the alternative ways of conceptualizing and interacting with animals and the environment developed by Caribbean peoples particularly significant — a topic which has seen little empirical examination. As an African Caribbean people whose moral consciousness is filtered through ancestral enslavement, Ndyukas mourn animals within an alternative environmental ethics of mutual autonomy. Though this ethics is indebted to an African past deeper than colonialism, it nevertheless runs counter to 
the denial of relatedness central to the colonial plantation capitalism from which Ndyuka ancestors freed themselves.

Ndyuka ethics is "haunted" (Derrida 1994, 2008; Wirtz 2018) by the scope of human responsibility to other beings and illustrates why, as Butler (2004, 21) argues, mourning involves "submitting to a transformation . . . the full result of which one cannot know in advance." Many Ndyukas certainly understand themselves as "becoming with" (Haraway 2007; Dave 2014) the animals with and from whom they live. Nonetheless, they resist this becoming. People work hard to maintain a clear, if ultimately porous, boundary between themselves and the animals with whom they share their rain forest society. It is these boundaries that transform when exposed to the ethical imperative of an animal's mournful rage at its own death.

\section{KUNU AND THE NDYUKA NATION}

Ndyukas are one of the many ethnic groups inhabiting Suriname, a small postcolonial country with a population of roughly 600,000 on the Atlantic coast of northeastern South America. As members of one of Suriname's six Maroon nations, Ndyukas descend from enslaved Africans who escaped from Dutch colonial sugar plantations in the eighteenth century to found independent and distinctively African American communities in Suriname's immense neotropical forests, swamps, and savannahs (Moomou 2004; Parris 2011; Thoden van Velzen and Hoogbergen 2011; Cunha 2018). Throughout 250 years of self-rule, Ndyukas have primarily relied on swidden cassava agriculture, foraging, and hunting to sustain themselves in their adopted rain forest homeland. More recently, however, many Ndyukas have been forced to leave their ancestral villages to pursue waged labor in Suriname's multiethnic capital and only city, Paramaribo, or mining and logging in the interior. Although their lives are increasingly urbanized, Ndyukas retain a unique relationship with the forests that sheltered their ancestors and the animals and plants that reside there.

Whether at parties in urban Ndyuka squatter settlements, or while hunting and gardening near rain forest villages, kunu were an inescapable, if whispered, presence throughout the twenty-five months of cumulative ethnographic fieldwork I conducted between 2007 and 2013 and a month-long visit in 2018. Ndyukas are both reluctant to talk about kunu - for fear of inciting them — and constantly doing so. Though human ghosts are the most prevalent and socially impactful category of kunu, trees, mammals, reptiles, and birds all have at least the potential to spawn avenging specters. Whatever their species, and whether in retaliation 
for intentional or inadvertent deaths, kunu inflict their fury on those whom they blame for their premature demise. Da Gali, the elderly leader of a village in the Ndyuka heartland, described the vengeance attributed to a kunu after an act of unprovoked violence that occurred at one of the many small goldmines that litter Ndyuka territory:

A couple of men saw a large boa [dagwe]. Five men then came to shoot it. The first shot high, because he realized the dangers of killing such a snake. But the other four men didn't think anything of killing it, and each shot at it . . . until it died. All four of them are dead now. One hanged himself. The next man died when his plane caught fire and exploded, killing all aboard. Another turned into an enormous snake so that everyone fled from him. The remorse he felt after murdering the snake led him to kill himself by becoming a snake. The last man went crazy and shot himself. But the man who [intentionally] missed, he is still alive. So, you see, constrictor kunu aren't something to make a joke of; they'll kill you!

Da Gali's story highlights the power of kunu to wreak havoc on the lives of their human killers. The four men directly implicated in the death of the constrictor die violently. Only the fifth, who played along but refrained from actually hurting the animal, remains unscathed. In narratives like Da Gali's, we see how murdering a snake who intended them no harm can literally transform killers into victims. This is the hallmark of kunu.

While Da Gali described an instance of a kunu directly targeting its killers, more commonly the misfortunes in which kunu manifest themselves are based in cruelties obscured by time and distance and require divination to be wrenched into collective awareness. This holds particularly true when kunu target members of the killer's matrilineal (and, occasionally, patrilineal) family. A story told by Sandra, a middle-aged housecleaner in Paramaribo, at the end of a long day of hard work exemplifies this:

A woman from the village of Tabiki wanted to take out some clothing she kept in a trunk in preparation for a dance. When she opened the trunk, she found a boa constrictor inside. She cried out and her relatives came and removed the snake and placed it in the river at the base of some rapids where it swam away downstream. When the woman woke up the next morning, she found [what she took for the same] snake coiled in the rafters of her 
house. She repeated her call for her kinsfolk to help her. There happened to be a shaman [papa obiyaman] present who knew about these things. He told her that the snake was there for a reason-otherwise it would not have returned to her house so quickly. The shaman then divined what the snake wanted. It transpired that the woman's deceased mother had killed the snake in her garden, causing it to suffer greatly. When the mother died, the snake's vengeance fell on her daughter. [After the divination the shaman] prepared everything and removed the snake to the place where it had been wronged by the woman's mother. There they prayed and prayed. They tried many different things to console the ghosts of the snakes that the woman's mother had burned to death in her garden and to whom they now gave proper funerals. Since that time, no snake has come to make demands of the woman or her family.

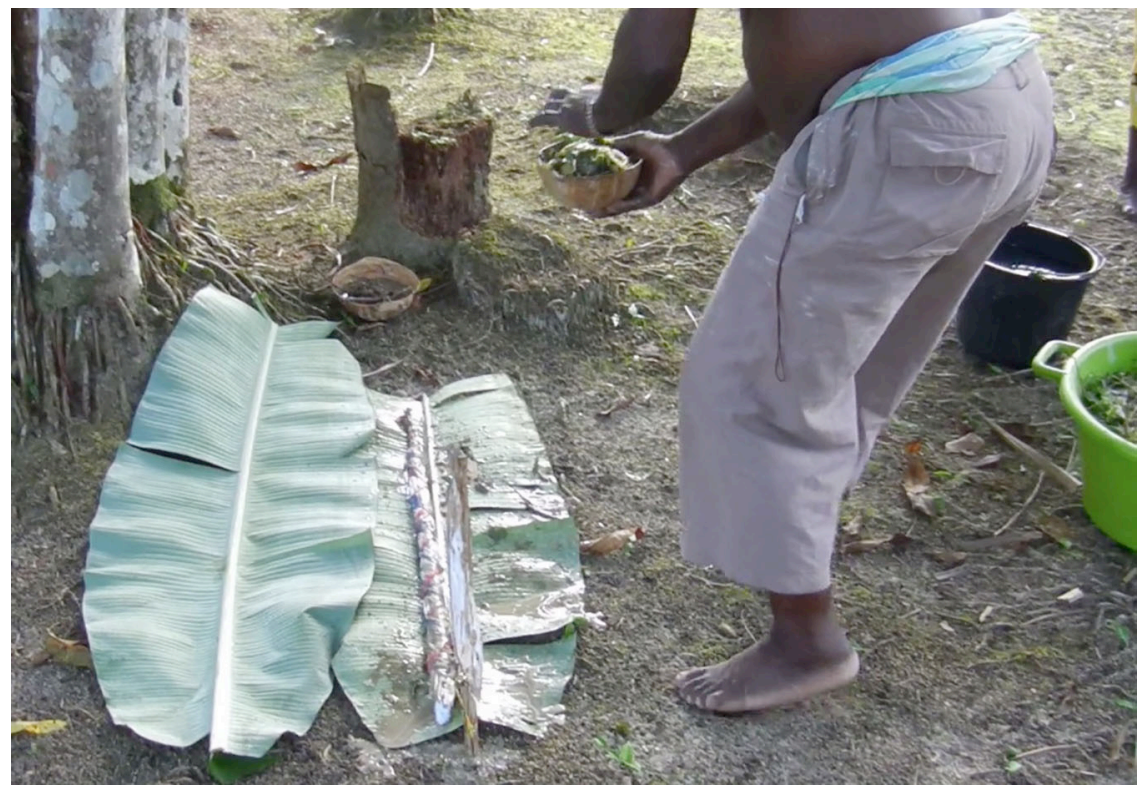

Figure 1. Preparing an effigy of a snake kunu in preparation for divination. Photo by Stuart Earle Strange.

In this anecdote, the snake kunu appears to warn the village woman and her kin that they would face severe retribution - and even annihilation - if they continued to ignore transgressions committed by the woman's mother against it and its kind many years earlier. Regardless of their ignorance of the wrongdoing, as relations of the transgressor, all were bound to the snake and needed to divine the source 
of this relationship to avoid becoming casualties of its anger. According to Sandra, the purity of the kunu's mournful rage qualified it to be both witness and judge of the woman's matriline's common guilt for neglecting to restrain her mother from her act of disrespect. The only amelioration for this rage was to mourn alongside the ghost that dispatched its living relatives as warnings and to extend to it the funerary grief that its violent death had denied to it and its family.

Writing about animal rights in India, Naisargi N. Dave $(2014,442)$ has observed that "the witness of violence is only a witness because she survives it - because she has witnessed, in fact, she has an obligation to live." Kunu exemplify this directive and carry it beyond death to make the obligation to persistently testify to past injustices an elementary social principle. In this way, kunu ricochet from unwarranted violence to force responsibility onto Ndyukas. This culpability warrants kunu to perpetually revisit the event of their suffering on the perpetrator's lineage. Unless placated through rites in which the guilty matriline confesses their collective culpability — such as the efforts described by Sandra to mollify the snakekunu will dedicate themselves to that matriline's extermination, something vividly captured by a friend's dream in which he saw his family's kunu in the shape of a large man crushing his lineage as so many palm fruits in a mortar.

Once corporately recognized through offerings and supplications, kunu do not go away but remain tutelary spirits of the lineage they afflict. In this role kunu surveil the lineage to make sure that its members show them the proper respect, and the kunu intervene through human mediums to impose resolutions to familial conflicts that threaten the lineage's ritual ability to perduringly express its collective guilt. Because a lineage's kunu are the most important guarantors of its long-term solidarity, these spirit tormenters become implanted in the lineage's genealogical endurance. The matriline can only maintain itself into the future as a cohesive entity through fear of the endless retributions that kunu threaten. This continuity, however, implies the eternal and involuntary return of the grief of others that the family caused and desperately hopes to be rid of. Lashed to the fate of the family by its unappeasable wrath, the kunu oversees the enforcement of cooperative contrition among those who have wronged it. This establishes an enduring asymmetry that grants the kunu's kin power over the extended family of the kunu's killer. Thus licensed, kunu install themselves in the lives and deaths of those who have victimized them for what many of the Ndyukas I spoke to described as "generations and generations without end."

In taking their revenge, kunu embody a characteristically Ndyuka ethics founded on mutual recognition (libi makandii) — the principle that others should 
not only be recognized as volitional beings with intrinsic dignity like oneself but also as instantiations of the social-metaphysical relations that imbue them with this volition and self-integrity. This is how Da John, my middle-aged research assistant who was raised in a traditional village and now works as a government bureaucrat in Paramaribo, explained this value with reference to constrictors:

If I see a constrictor I won't kill it because it hasn't done anything to me. But when it gives me difficulties, like if it catches animals that I've raised-say, a dog or some chickens-I will kill it because it has sought me out to make trouble for me. A constrictor that I've killed in defense won't become a kunu. But if I were to kill it for no reason, then it will become a kunu for me, and for my children and their children.

By this account moral flourishing means responsibly conceding subjective differences and letting others and those they care for respectfully alone. Kunu's collective vengeance is appropriate because, in selfishly killing someone else, a murderer violates the mutuality of this recognition.

Such infringements on the independence of others undermine the "relational autonomy" (Mackenzie 2008) — the self-determination that comes with awareness of how the self is inosculated from multiple interrelations with others - that defines Ndyuka persons and imbues them with agential cohesiveness. Ndyukas understand persons to be bounded multiplicities (Strange 2016). Like the lineages that they compose, Ndyuka persons are simultaneously singular and made up of a collective of inherited agents, both living and dead. A unique aggregate of ancestral and tutelary spirits is therefore present in each person's thoughts, feelings, agency, and dispositions (for other Caribbean examples, see Espírito Santo 2015; Wekker 2006). Every person is distinct because no two people are made from the same overlap of these relations. The peculiarity of each person's relational matrix encourages them to seek autonomous social influence and respect — often through rituals that minimize their vulnerability to new relations beyond those that either already define them or which they actively choose, like a spouse.

This notion of personhood applies to nonhumans as well. A snake, like a human or a spirit, while singular, is therefore also multiple - individual snakes stand for the whole of their kind in a given territory. As happened to the Tabiki villager, when one snake is killed, it therefore returns to testify through its conspecifics. In this way, all persons embody specific genealogies rooted in particular territories. History and place are largely identical for Ndyukas, with lineal identities founded 
on claims of inalienable residence in a definite area that stem from ancestral transgression against the spirits who reside there. If an outsider trespasses on a lineage's land, any member of the resident lineage may suffer retribution. Ndyuka theories of personal and lineal autonomy accordingly draw no hard distinction between individual and collective. Particular places and people reveal histories of relatedness that entail further relations. To interact with another person-whether human, animal, or plant - is to simultaneously engage with the whole history of that person's family, lineage, clan, and territory. Correspondingly, every place denotes all the possible residents who have lived there in the past and present and who consequently have a right to remain there unmolested into the future. To deny another's right to this autonomous existence is to also repudiate all those who are co-implicated in their presence.

By dragging whole lineages into involuntary mourning, kunu remind discretely embodied Ndyuka subjects that although personal autonomy is desirable it is always contingent on first recognizing the independence of others. In this regard, the ethics of kunu emphatically dissents from the necropolitics of the racial capitalist enslavement from which Ndyuka ancestors liberated themselves. No living person has the right to decide the value of another's life or death-something very different from the dominant assumptions of the Euro-American political-economic tradition. Rather than treat others as means to an end, in almost Kantian fashion, a person must try and see themselves from the standpoint of the intrinsic dignity with which all persons are imbued by virtue of their being collectives composed of bundled ancestral, spirit, and kin relations. Acknowledging this dignity is what creates the "respectful" relational distance that upholds personal and collective autonomy within such an interdependent reality (see also Keane 2014). Violating another's autonomy is what inflicts the aggrievement that warrants them to return from the dead as kunu. As the shaman Da Mangwa described to me, once killed, infuriated future kunu wander the halls of God's heavenly bureaucracy pounding on doors until they make such abject nuisances of themselves that they are granted the right to revenge. In this way, kunu make the enraged grief that Renato Rosaldo (1993) described as the motivation for Ilongot headhunting in the Philippines into a basic principle of Ndyuka sociality. According to Da John, "kunu come back to kill [their killer's] descendants so as to make [the killer's] own family feel the same grief that the kunu's family felt. The same loss that the kunu's family experienced, the feeling of emptiness that his family feels, is what the kunu wants to make his killer's family feel as well." Kunu are not merely infuriated by their own deaths but also maddened at the festering social wound inflicted by having 
been wrenched from their many relations. As personifications of the unbearable urge of the aggrieved to strike back, kunu return to the world in patterns of death and misery that are supposed to push their targets to experience the kunu's own pain and rage. Kunu accordingly abolish any distinction between the subject and object of mourning and compel everyone involved, however tenuously, to experience the socially constitutive power of grief.

Such uncontrollable grief constitutes an unavoidable facet of Ndyuka mourning. Funerals dominate Ndyuka social life and involve large-scale coordination among family members and considerable financial expense over many months. At funerals - of which I attended at least twenty during fieldwork - it is not uncommon to see people of all ages collapse sobbing on the ground while more distant relations fight to restrain them from upsetting the coffin or dragging down the wailing mourners who accompany the corpse to the grave. But unlike living mourners - whose emotion is exposed so that they may eventually move beyond their debilitating grief - kunu work to make sorrow perpetual and inheritable. Against the urge to bury historical injustices, kunu unshakably stitch contemporary suffering to past offenses and force them to be collectively mourned.

In coming back, kunu secure a place of moral objectivity exclusively grounded in transpersonal subjective suffering. The event of their death is the emotion of a spirit's moral outrage at the failure of others to recognize their intrinsic autonomy. The intensity of this vested interest reifies the spirit's anger into an immanent ontological truth, a grief that must be felt by others. The divination and mediumship that animate a kunu's testimony therefore prove critical to Ndyuka "political subjectification," and kunu comprise the key "ordeal of truth" to which all Ndyukas are submitted (Fassin 2008, 533). For many Ndyukas, the witness offered by kunu divulges the ultimate moral and epistemic insufficiency of living humans. Kunu are the truth that induces otherwise grudging humans into proper recognition of the reality that their ostensibly autonomous agency is contingent on their family's collective responsibility for past injustices.

\section{THE REVENGE OF ANIMALS}

Animals (meti) occupy a complicated place in Ndyuka imaginations. Many Ndyukas regard animals as simply "other than human persons" (Hallowell 1960). Given that Ndyukas are quick to revile humans as "evil" (ogii), what this shared personhood implies is open to interpretation. Some people take a modified "perspectival" (Viveiros de Castro 2012) stance and feel that animals consider themselves superior to humans in the same way that humans feel themselves to be bet- 
ter than animals; hunters and miners even describe sites in the forest where jaguars or peccaries concoct magical baths (obiya) — the main Ndyuka technology of ritual power - to aid in their struggles against both humans and each other. Others denigrate animals as "stupid," and comparisons with animals are potent insults. There is general consensus, however, that animals possess their own languages (which some elders are reputed to have understood in the past), are ensouled, and live in societies similar to those of Ndyukas themselves.

Despite the controversies, Ndyukas acknowledge that humans and animals share a common moral universe in which power is always laden with unwanted relations with those who fall victim to it. When representatives of the Surinamese government approached the previous Ndyuka paramount chief, Gazon Matodya, about damming the Tapanahoni River upstream from the Ndyuka homeland, he reportedly asked them to get the permission of all the animals and plants in the area. Inquiring what right the state had to destroy the homes of other beings without their consent, Da Gazon made his fear of the vengeance incited by such mass nonhuman death the centerpiece of his opposition. Any number of nonhumans might do harm as a result of such infringements on the due respect that is either owed to them or to a spirit that employs them as its "vehicle." Family members who have deformities inflicted by animals_-such as a man described by his kin as having the face of a caiman (Caiman crocodilus) illicitly shot by his father-are often used to illustrate these dangers. Such resemblances are regarded as evidence that, even if often only posthumously, animals are able to testify to their belonging within a mutual multispecies ethics.

This ethics is based on the distinction between forest and village. Beyond the village lies a parallel forest zone that, while having the same generic "laws" (weiti) as Ndyuka settlements, belongs to nonhuman others with divergent interests. Unlike the philosopher Val Plumwood's (2012) surprise at her near demise in the jaws of a crocodile, most Ndyukas accept that they might always become another creature's meat when they enter territory not their own. It is therefore both true that humans should never harm certain animals and that they might very well feel driven to do so. Though they may be persons, in a society traditionally without domesticated animals other than dogs and chickens, most animals are wild and viewed as either threats or food. These identities are also moral positions defined by the animal's subjective autonomy from human beings. Da Yomoi, a captain in the Ndyuka village where I lived, has furrowed scars across his scalp from a childhood jaguar attack. The jaguar had Da Yomoi's head firmly in his jaws when his father rescued him. Confronting the jaguar, Yomoi's father dared him to try himself 
against a more evenly matched opponent. Dropping the boy, the jaguar pounced but was shot down with a magically medicated shotgun shell. Da Yomoi's story elucidates that a transspecies commitment to respect is an ethical precondition that ripples across the whole "society of nature" (Descola 1996). Though it is perfectly in the character of jaguars to eat young children, Ndyuka expectations about interpersonal competition mean that for jaguars, as for humans, an easy meal cannot compete with a chance to display superior skill against a formidable opponent.

Such encounters entail risks that position humans and animals within a conjoint understanding of the wider relational implications of violence. As already described, to legitimately execute a kunu's mission, the aggrieved victim must be a blameless casualty of another's unbridled aggression. Kunu calculate the degree to which violence is rash or responsible. Such considerations mean that, while many kinds of animals can rebuke humans who disrespect them, not every animal can become a kunu. Dangerous animals like poisonous snakes or jaguars are ruled out from transforming into kunu. While some people hold that it is possible to incite reprisal by killing an unfairly vulnerable jaguar, because jaguars eat humans, it is more customarily held that humans have a preemptive right to defend themselves. Like murderers, animals that attack humans neutralize any entitlement to posthumous revenge.

Kunu animals are also distinguished from non-kunu animals by whether or not they are considered legitimate game. A creature that Ndyuka people eat should not become a kunu. The hunter Ba Michel maintained that, since he survived by consuming them, he did not need to respect any animal that he hunted. Just as a human eaten by a jaguar will not become the jaguar's kunu, because humans are carnivorous, they cannot have abiding ethical relations with prey on whom they subsist. Others, however, disputed the scope of this rule. Da Mangwa told me about how a pregnant spider monkey (kwata; Ateles paniscus) looked at him imploringly and pointed at her stomach to stop him from shooting her. Although spider monkeys are food, according to Da Mangwa, killing the pregnant monkey would have transformed her into his kunu because it disrespected her species' right to intergenerational continuity.

Mutual respect is clearest in the case of the two kinds of animals consistently thought to become kunu-dogs and constrictor snakes. Most Ndyukas imagine dogs chiefly as collaborators in hunting. Dog and hunter rely on each other. Chasing dangerous quarry through near-impassable forests where visibility rarely extends beyond the nearest tree requires trust. The abrogation of this trust is the reason why dogs transmogrify into kunu. The very domesticity of dogs, the way 
in which people live with them in villages, train them, and treat them with powerful proprietary hunting magic, makes them intimates and impels a lasting interdependence. Dogs look back as individualized beings with names and identities enmeshed in reciprocal acts of care. Like all kunu, vengeful dog spirits result from unexpected violence - especially when committed by a dog's caretaker. Such betrayals demand redress and authorize dogs, above all other animals, to return as ferocious witnesses to human treachery. Although disputed, a number of people told me that the same applies to other pets such as monkeys and macaws.

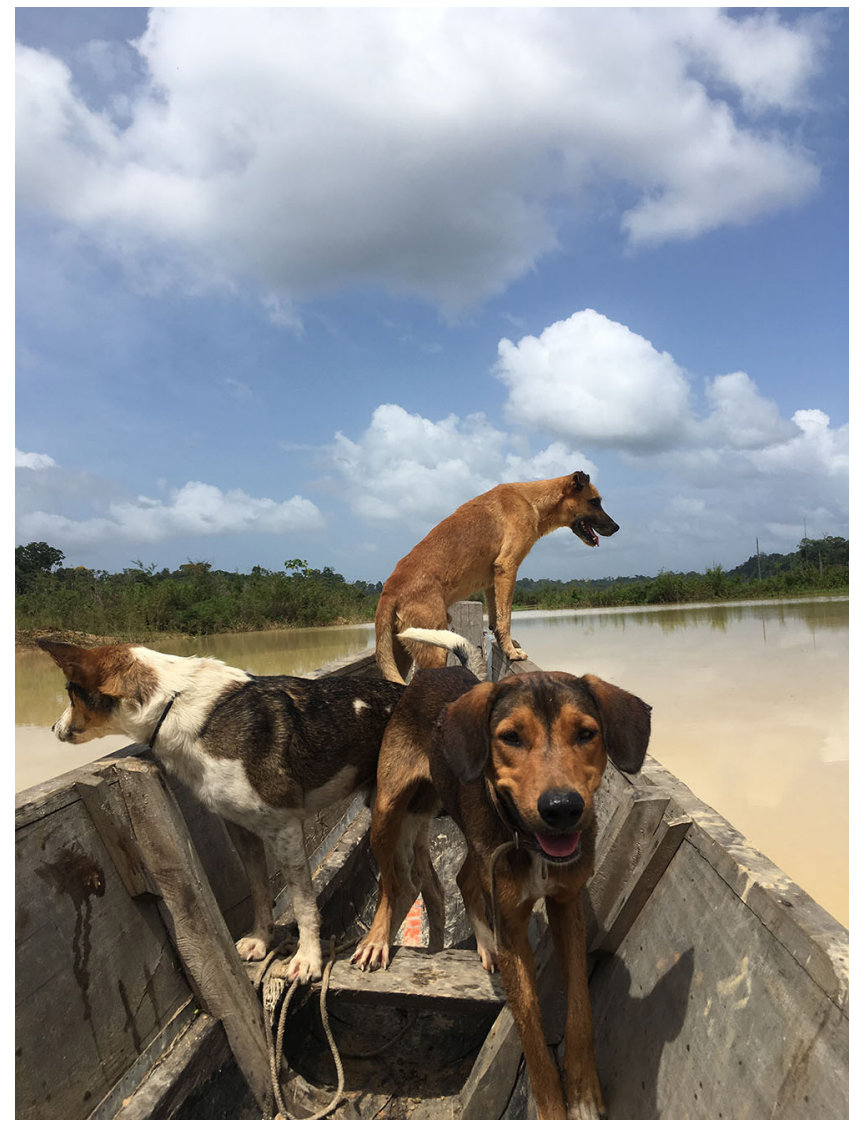

Figure 2. Ba Michel's hunting dogs. Photo by Stuart Earle Strange.

Expanding humanizing care to an otherwise killable animal brings it incontestably within the ethical prescriptions of mutuality over which kunu menace like thunderclouds. The snakes that become kunu are altogether different. Visibly unlike pet mammals and birds, snakes are thought of with horror and assiduously 
avoided. People even refuse to look at them; Da Robby, an expert mortuary ritualist, described his visceral fear of constrictors, the sight of which causes his "body to tremble" and his mind to run wild with thoughts about what he might have done to deserve the snake's hostility. There are two categories of snake that become kunu, both of which are constrictors: boas (Dagwe/Papa; Constrictor constrictor) and anacondas (Fodu/Mboma; Eunectes murinus). These are commonly found in the many streams and large rivers that crisscross Suriname's rain forests and savannahs. Anacondas are almost exclusively aquatic; boas move between trees, waterways, and the forest floor and especially like to nestle into other animals' burrows. While theoretically dangerous, constrictors normally show no interest in humans. Considering their impressive sizes - up to three meters for boas, as large as five meters for anacondas - these snakes are unique in occupying the forest of Ndyuka territory without presenting an immediate physical threat. Their stolidness in the face of human encroachment makes them unsettling witnesses to the independent agency of the land. This attribute critically determines how Ndyukas handle them. In the words of Da John:

If a snake in the forest blocks my path, I'll look for a way around it. But if I see the snake in my garden, I'll speak respectfully to it until it goes. . . If the snake doesn't go after being spoken to, I'll cut a stalk and whip it while I explain myself until the snake has entered the forest and I can stop because the forest is the country that God made for snakes. If I'm clearing a garden, it is a different matter. In that case, before I cut anything, I prepare an herbal formula in a calabash and wash the ground with it. This is only to remove the beings that live in that place. Before you can do this, you need to know what sort of entities reside there so that you can invoke them and ask their pardon for taking their home. If a snake comes after you've already planted, then you must remind it that you've already made a deal with it to leave. If it continues to return, then you can respectfully drive it into the forest.

Addressing the snake affirms that it is a moral subject who deserves respect. It also enables humans to negotiate with animals in ways that may not so subtly coax them beyond the boundary of human relations. As described in Da John's account of gently whipping a stubborn snake, such negotiations often prove coercive and assume that humans have a valid and ever-expanding prerogative to plant, hunt, or mine wherever opportunities arise. Though many locations are ruled out for 
human use by the presence of specific trees or landscape features, animals can nonetheless be induced to give up their rights in favor of human interests.

Animal kunu, however, contest the boundlessness of such human self-interest. By furiously hijacking a lineage's collective future, animal kunu impose restraints on human agency and punish its thoughtless excesses. As seen in Sandra's story about the Tabiki village woman recounted earlier, most constrictor kunu are casualties of the day-to-day practices of Ndyuka agriculture, which requires that small plots of cleared forest first be burned to infuse the rather poor tropical soil with needed nutrients. These fires and other disturbances like felling trees create the majority of serpent kunu. Their vengeance, in turn, reminds humans that the land they use is never entirely their own and that they must never take access to its wealth for granted.

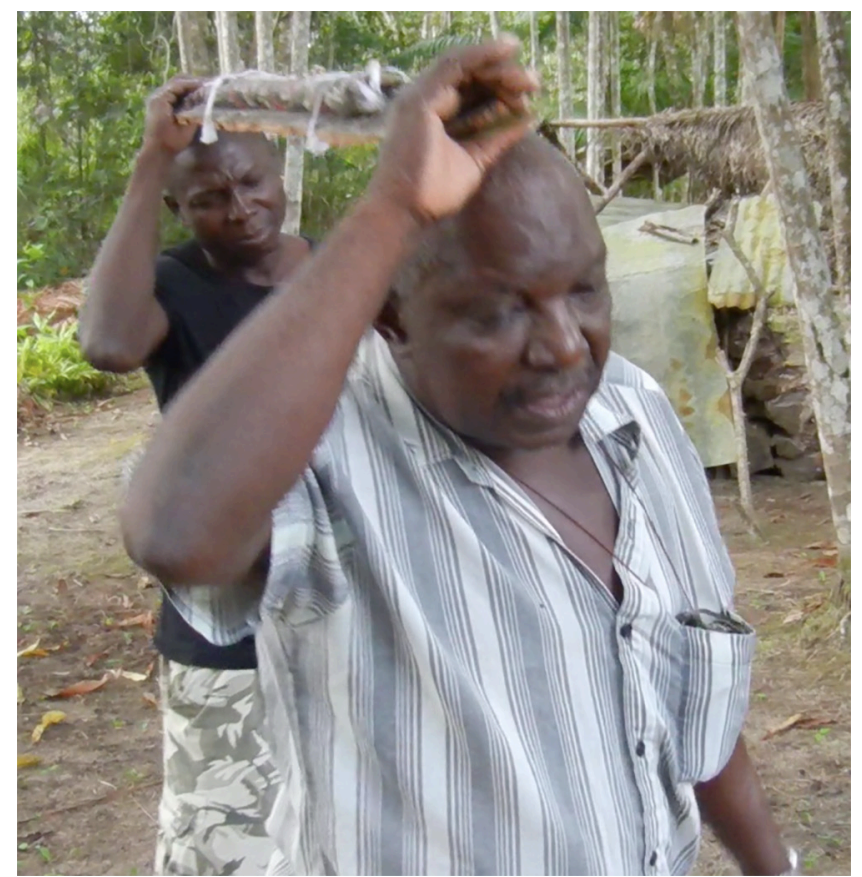

Figure 3. Consulting a carry oracle of a snake kunu. Photo by Stuart Earle Strange.

The ubiquity of such accidental deaths makes constrictors one of the most common possessing spirits, especially for women, who do most of the agricultural labor. Though a gardener might later find a tattered snake skin or some charred bones, it is more likely that, as seen with the Tabiki villager, a snake's death is only retroactively divined. The frequency of such discoveries makes snakes a powerful 
genus of Ndyuka spirits - an influence indicated by the fact that at least three of the major oracular deities with jurisdiction over the whole Ndyuka nation are imagined to assume a serpent form. Indeed, as the presiding spirits of places (goonmama), constrictors can even vengefully cause the conception of human children, and when properly propitiated for trespasses against them, bestow health and good fortune.

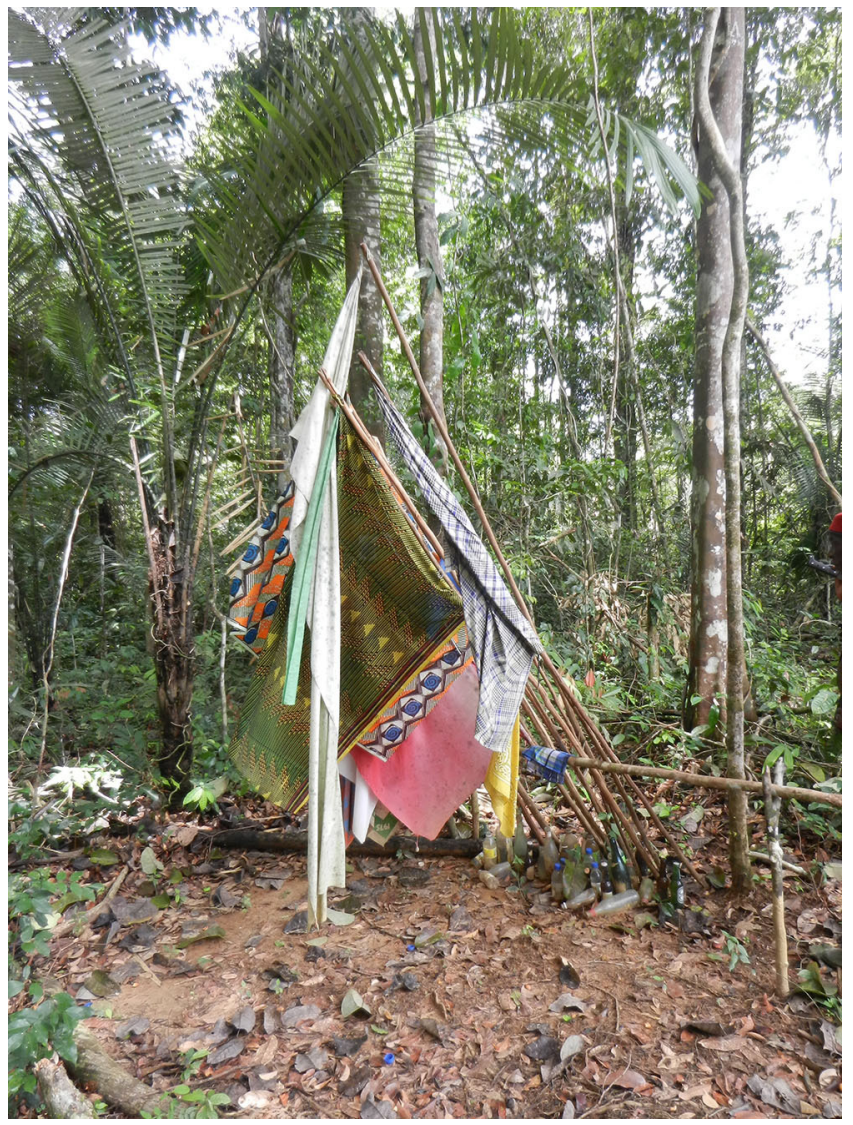

Figure 4. Shrine for a place's Goonmama spirit. Photo by Stuart Earle Strange.

Constrictors are in other ways also more in keeping with Ndyuka notions of spirits than most other animal kunu. Because Ndyuka families and selves are understood as literally made of a diverse array of ancestrally mediated spirits, their containment of these manifold agencies is considered involuntary. As with snakes, people strive to keep their distance from spirits, and it is only through mishap that spirits impress themselves onto living humans. As Da John emphasized, encountering a snake or spirit outside its domain constitutes a stern warning: 
If you see a constrictor in your house, then you should call a papa obiyaman to come and remove the snake for you. Afterward, he will purify your home and divine where you offended the snake. This is because it isn't for nothing that the snake has come to your house. After they have caught the snake, they'll pray and tell it that it is within its rights, that it shouldn't be offended, and that it should change its course of action, because any offense that was caused was purely accidental.

Ndyukas counter the involuntary relation demanded by a deceased snake with the inadvertency of the offense against it. By disclaiming that selfish intentions and emotions of the sort that ruin human social relations played any part in their death, Ndyukas attempt to soothe animals out of their lives. As in Peter Strawson's (1962) discussion of the moral gulf that divides intentionally stepping on someone's foot from accidentally doing so, Ndyukas are at pains to redefine their actions as unwitting and to thereby escape the inseverable familiarity with kunu generated by actively wanting to harm others.

The differences in the intimacy of the violence that turns dogs and constrictors into kunu highlights the contrast between them. The faithful dog, already familiar, transmogrifies into a wrathful kunu when treated as though it were mere meat or a dangerous forest animal and is inconsiderately killed. Conversely, it is the self-evident distance of constrictors from village life, the effortlessness with which they blend into and command their rain forest habitat, that turns the alien snake into an intimate kunu. While dogs resemble humans in their sociability, constrictors are solitary and either avoid humans or seek to scare them away. Dogs display evident intersubjectivity; snakes, an apparently impenetrable otherness. The dependable and indispensable domestic dog and the strange jungle-dwelling snake therefore occupy opposed poles of Ndyuka sociality. Yet both animals are nonetheless defined by their infiltrations of the other's domain: dogs aggressively pursue game through even the most forbidding bush; constrictors enter into villages to warn and chastise humans for their disrespect of the forest's independence. Ndyukas stress these clear dissimilarities and yet arrive at similar conclusions about these species' propensities to punish humans for failing to consider their responsibilities to them as autonomous beings with dignity all their own.

\section{MUTUALITY AND THE LIMITS OF AUTONOMY}

By demonstrating that responding to others as autonomous subjects offers the best means of avoiding future grief, constrictors and dogs analogously encap- 
sulate the Ndyuka ethics of autonomy. To willfully infringe on another's due right to exist without acknowledging them forces the animal (or human) so wronged to become a kunu. This means that people have no option but to incessantly strive to assuage those whom they have mistreated by anticipating their discontent. Da Labi Gazon, an elderly miner who resides in the city between months-long stints of laboring in the goldmines, illustrated this with a story:

If I see a boa constrictor, I won't kill it, but will instead look for another route around it. Because that is the snake's country there; I won't go looking for problems with it. Another man and I went to the forest. There we spotted an agouti [Dasyprocta leporine]. . . The agouti squealed and ran off, and we decided that we would catch it. [We agreed] that I should walk on one side of a creek, and the other man would walk on the other side, and then we would shoot [the agouti]. I walked along the creek so that the agouti wouldn't hear my footsteps. I walked until I saw one very large old tree that had fallen across the creek and had sagged in the middle in conformity with the creek's banks. I thought to myself that I would use the tree to cross the creek and gain a good vantage from which to shoot the agouti. I walked three meters until I reached the place where I would begin to climb the tree. It was then that I saw the colors. It wasn't a tree at all but an enormous snake! I went back and cried out to the other man that he should hurry over. When he arrived, I told him to look carefully at the tree. When he realized that it was a snake, he jumped back with fear, exclaiming about how large the snake was. I said, yes, dagwe snakes can get very big. Because we were speaking about her, the snake understood and began to slither forward until she was entirely in the middle of the stream. There she completely submerged herself, "gbolong!" agitating the leaf-littered waters until they swelled up high . . . when you see something like that then you just know that something is there in that place.

The other man and I talked. We decided to continue our hunt because the snake had obstructed the agouti's path. The other man began to talk [to the snake], saying that, with a little more [effort] we could catch the agouti. But now we've [accidentally] deprived you of your prey, and we haven't caught the agouti either; you mustn't be angry because we are also hunting and didn't know to talk with you about whether you saw the agouti first and wanted to catch it. Then we besought the snake, telling her, "You are justified to take the agouti, but please take a different one. We're not here to wrong you, 
all we want is to find food." [After we implored the snake in this way] we left that place and encountered and shot so many animals and birds that we couldn't even carry them all home.

Even as he trod on the snake's back, Da Labi initially misrecognized her- displaying a fittedness to place that shows why these snakes are so strongly associated with the land. Once he identified the snake, however, he accepted that they shared a common purpose in hunting the agouti. Conceding his fault, Da Labi and his friend vocally accepted the snake's spatial and temporal priority and found themselves rewarded for their humility with the abundant prey that indicates the snake as the "owner" (masáa) of the territory. Here, mutual need provides a common ethical ground on which Da Labi and the snake can respectfully distance themselves from one another. Once they have worked out their differences, their common needs can converge. This harmonization of human and animal intentions does not bring Da Labi and the snake together. Instead, it generates a guarded intersubjectivity that reciprocally preserves the other's autonomy. In a fully relational reality, such autonomy makes for a crucial yet precarious achievement. Had Da Labi harmed the snake, or even simply failed to recognize her interests, this affront would have driven her to become a kunu.

Da Labi describes how Ndyukas endeavor to maximize their autonomy by limiting relational exposure and cultivating mutual respect in which autonomy can thrive. Ndyukas know that their individualized bodies and personalities are, in the final account, the residue of communal ancestral histories. This very awareness of the relational fundament of personal agency and identity makes preserving the unhindered and unreflective everyday independence of oneself and one's kin all the more valuable. Personal autonomy is not guaranteed but rather constitutes a sustained accomplishment of knowing how to live with pervasive relatedness. Because any interaction can generate a cascade of future compulsory relations of mourning with whomever you are interacting with, the goal is to regulate relations with others by learning to give them their due independence.

In a world suffused with hidden relations, however, this strategy must sooner or later fail. For Ndyukas, involvement in another's life exposes the metaphysical depths of the relation that connects people in death. Grief is consequently the opposite of respectful distance and the autonomy it ensures. To grieve is to succumb to relatedness. No one wants to grieve; people are forced to mourn because their relationship with the deceased forms part of them-because it is them. Whether with spouses, kinfolk, or unfairly treated enemies, relations are synonymous with 
death because they imply the intensified interdependencies that make grief inevitable. For Ndyukas, to be related is to mourn.

Ndyukas struggle for autonomy precisely because it is opposed to death and grief. At every scale of Ndyuka society, grief cajoles people to come together and recognize their irrevocable co-constitution. Not only does death reveal the consuming emotions that accompany loss but it likewise emphasizes the familial relations through which mortality, in all its contagiousness, emanates. The elaborate rituals with which Ndyukas answer death are designed to intercept the septicity of this grief, so that it will not become enshrined as a kunu in a family or lineage's future.

Ndyukas resent kunu for binding them to death and mourning in ways that further erode their autonomy as both discreetly embodied persons and members of lineages. Ndyukas accordingly desire that funerals for animal kunu mirror human funerals in decisively severing the dead from the living so that they no longer intervene in peoples' daily lives. At one funeral I attended for a snake kunu, the kunu-afflicted family revolted when the carry oracle - a medicated plank carried on the heads of two human bearers that communicates by directing their movements (see Figure 3) — of the presiding shaman instructed them to build the snake a small shrine where routine libations could be poured to mourn its untimely death in a garden fire. Refusing any such lasting responsibility, the family pressed the shaman to make the spirit agree to burial in an inconspicuous grove where all marks of its existence would quickly weather away and leave them free from its future demands. While the shaman relented to the family's wishes, he did so only reluctantly and appeared dubious that such a conclusive resolution was possible.

Despite such attempts at divestment, Ndyuka ritual mourning for animal kunu enforces a fusion of standpoints. As with Da Gali's story in which a goldminer who killed a constrictor is himself transformed into a snake, violence invites different beings into one another's bodies. Killing a person denies, but does not eliminate, the autonomy of their viewpoint. Rather than extinguishing the other, such violence simply defers and intensifies eventual interdependence. When the kunu finally erupts within the collective life of its murderer, the whole of the killer's lineage is also forced to witness itself from the perspective of the outraged kunu.

Kunu animals do not, then, simply become objects in human projects. Through the ways in which kunu lay hold of human bodies and lineages, Ndyukas "indeed become . . . animal, not theoretically but carnally, morally, spiritually" (Dave 2014, 435). Kunu animals enter into the physicality of human existence and 
animate it with a socially fulsome, and immanently moral, animality. As with Da Labi earlier, to negotiate a settlement in which animals deign to respect human autonomy, Ndyukas are compelled to assume the interests of at least some of their animal others. When Ndyukas become these animals in this way, they do so as incomplete ciphers for their own ethical violations of this reciprocity. By feeling these animals' real or potential grief, they enter into an intersubjectivity that discerns the world through the animal's eyes and body without claiming full knowledge of what it finally means to be that animal. Once recognized by an afflicted family, snake spirits publicly possess their spirit mediums at ritual celebrations to try and pry some enjoyment out of their tragic ensnarement in human life. Dusting their bodies with jarringly white kaolin clay, constrictor mediums join their hands in the shape of a snake's head and writhe rhythmically in serpentine dances that enact the merging of human and animal lives and deaths. Mediums themselves, like mourners consumed by grief, cannot speak of these experiences of irresistible animality except as pregnant voids of inchoate feeling (see also Lambek 1981; Crosson 2017). Human is not strictly rendered animal, nor animal human. In lieu of an affirming or negating transformation, what remains is the incompleteness of a subjectivity suspended between human selves and animal others.

By existentially enmeshing humans in the ethics of mutuality, animal kunu reveal to Ndyukas that personal autonomy is a collaborative accomplishment that will be lost as soon as this truth is forgotten. While kunu are a major cause of enmity, fear, and suspicion, they propound that this ethics, though debated, is inviolable. Kunu thus transform grief into the affective armature of Ndyuka collective existence. From within the unfortunate events that beset life, the wronged other stares out in condemnation and those complicit in their distress are forced to mourn alongside them. Ndyukas sometimes denounce such communal accountability as unfair; they also hold that it is inevitable. Animal kunu proclaim to Ndyukas that they have no choice but to grieve for others - life itself depends on it.

\section{CONCLUSION}

Multispecies ethnography and animal studies demand attention to the irreducible interrelatedness of humans and other species (Gruen 2014; Kirksey 2015; Govindrajan 2017; García 2019). From this realization arises a profound question of what human responsibility means in such an entangled world. Ndyuka relations with animal kunu provide one vantage from which to consider this question. Ndyuka ethics of autonomy redefine necropolitics, changing its ultimate meaning from one of who can be "legitimately" killed or exploited to who will 
be held responsible for mourning another's death. In this ethics, human autonomy originates in learning to acknowledge interdependence to achieve qualified independence from the obligation to mourn. Contrary to presumptions of a clear break between a self-sovereign human freedom and its environmental conditions of possibility, kunu force Ndyukas to accept that projects of personal and collective autonomy are intergenerational and relational "achievements" negotiated alongside nonhuman others within a shared social reality of death (Van Dooren 2014). The integrity of humans as relatively autonomous beings comprising a relatively autonomous species consequently depends on the myriad of more-than-humans who have accompanied us in becoming whatever it is we are still becoming. At the very least, Ndyukas admit that grief compels relations that overwhelm fragile projects of personal and genealogical self-determination, and that mourning strips away the deceit of ever having been truly autonomous in the first place. From this admission springs an alternative conception of autonomy in which freedom only becomes possible when the full extent of human responsibility for the liberty of nonhuman others has been recognized.

Much as grief reveals the tragic truth of interrelatedness for Ndyukas, so the current crisis of mass extinction dissolves illusions of human autonomy. Neither the ethical implications of common biological descent nor the ostentatious despoiling of the environment has in any way hindered political-economic ideologies of perpetual economic growth rooted in the longue durée of white supremacy that are rapidly reducing the earth to uninhabitability. As the ghosts of the untold species killed by habitat destruction, exploitation, and climate change continue to proliferate, even if humanity survives, the question of what responsibility for mourning them really entails can only become more urgent.

According to Charles L. Briggs (2014, 326), anthropology is the "work of mourning" because "anthropologists make their own stories, but they do not make them just as they please; they do not make them under circumstances entirely chosen by themselves." Like mourners, anthropologists become witnesses to loss, and anthropology the multifaceted testimony to our inseverable relations with others (García 2019). These relations remain the poignant tragedy that animates the common reality binding us together as a collective (Butler 2004; Wirtz 2018). It is only by taking responsibility for the ecological extent of these relations that we can hope to attain the autonomy uncontaminated by others' grief that endures as the aim of so much liberatory human politics. Our autonomy is a fragile collective achievement that depends on how we recognize that others' deaths will eventually degrade and destroy any sense in which we may have ever been free ourselves. 
Ndyukas acknowledge these mortal foundations and build a theory of autonomy that makes the recognition of others the root of human freedom.

Ndyuka animal kunu consequently lend witness to a human obligation to "hold open space in the world for other living beings" (Van Dooren 2014, 33). More emphatically still, kunu imply that, while we may not yet feel that the deaths of other species curtail human ambitions, these deaths must inevitably exact an existential cost. As untold numbers of other species succumb to mass death, our grief will intensify. These ghosts will cry out ever louder from the background of our increasingly impoverished lives. This grief will reveal that the pervasive denial of relatedness that defines our present was only ever a delusion. Much as kunu force Ndyukas to take collective responsibility for what happens on their land and to others, so mass extinction will compel us to bear witness to the irrevocably relational world in which we live and to find new ways of acknowledging our responsibility for it. Indeed, the very integrity of life depends on it.

\section{ABSTRACT}

This article reflects on mourning and interspecies responsibility. Considering what Ndyuka Maroons in the Caribbean country of Suriname-historic fugitives from plantation capitalism - call kunu (avenging ghosts) I explore how Ndyukas attempt to secure personal and collective autonomy in an expansively relational reality where mourning is the quintessence of relatedness. Because grief impinges on Ndyuka autonomy, daily life is understood as a flawed struggle to maintain freedom from mourning. This can only be done by paying appropriate respect to others so that they do not return as vengeful spirits dedicated to the destruction of those who have harmed them and their entire families in perpetuity. This essay examines the ethics of such deeply relational notions of autonomy and ponders its implications for understanding accountability for anthropogenic extinction. [autonomy; multispecies ethics; grief; mourning; relatedness; responsibility]

\section{ON SA A SIKIIFI YA WANI TAKI}

A sikiifi ya taki fu a fasi di Ndyuka sama e tyai fuka anga sowtu faantiwowtu de fu den meti di e kon toon libisama kunu. A e taki tu fu sani di sa pasa te libisama kii wan libi libi sani di o toon kunu, anga fa libi sama mu dini kunu fu den sa libi makandii a wan fii fasi. Te wan sama dede, da ala sama fu a famii e tyai a fuka de makandii. Te wan kunu kon a wan famii, da a sa meke a famii fu a sama di be kii en tyai a fuka de soseefi tu. Libisama ná e wani fu tyai a fuka, ma a kunu sa meke den tyai en namo namo, bika a so wan fasi a o meke den fii a seefi tyali di en famii be fii, di den kii en. Fu di kunu a wani sani di de tuu tuu, da libisama mu libi a wan lesipeki fasi fu den no mu meke kunu gi den famii di o tan fika gi den baka pikin 
fu pikin, paansu fu paansu. A sikiifi ya e taki tu fu a fasi di Ndyuka sama denki fu libi anga den busi sani, anga fa den mu meke mofu a makandii fu libi anga den sani di sa toon kunu, fu a no mu poti den a fuka. A sikiifi ya taki en so, bika somen sama ná e lesipeki den sowtu a sowtu meti ya, ofuso den bon, anga soseefi den peesi pe den e tan fu libi moo. A toli ya e soi taki Ndyuka sama abi fuu koni di sa leli den bakaasama fu soi den fa den mu libi a wan lesipeki fasi di o meke den ná o poli a goontapu, ma den o tan libi bun bun anga taawan. [libi fii; libi makandii anga meti; tyali; adyumadye; faantiwowtu]

\section{NOTES}

Acknowledgments This article is dedicated to Tosca Koch, who will always be mourned. I want to graciously acknowledge grants from the National Science Foundation (Award \#1123530), the Social Science Research Council, the Wenner-Gren Foundation, the University of Michigan, and Yale-NUS College for supporting this research. This article could not have been written without the help of John and Giermo Willems and numerous other Ndyuka teachers and friends. Special thanks are also owed to Geoffrey Hughes, Kristina Wirtz, Liana Chua, and Erik Mueggler. Gabriele Koch provided inimitable support and invaluable editorial advice. I also wish to express my gratitude to the anonymous reviewers and Chris Nelson for their incisive feedback and numerous helpful suggestions and for the help of the Cultural Anthropology editorial team.

\section{REFERENCES}

Blanchette, Alex

2018 “Industrial Meat Production.” Annual Review of Anthropology 47: 185-99. http:// dx.doi.org/10.1146/annurev-anthro-102317-050206.

Boisseron, Bénédicte

2018 Afro-Dog: Blackness and the Animal Question. New York: Columbia University Press. Briggs, Charles L.

2014 “Dear Dr. Freud.” Cultural Anthropology 29, no. 2: 312-43. https://doi.org/10. 14506/ca29.2.08.

Brown, Vincent

2008 The Reaper's Garden: Death and Power in the World of Atlantic Slavery. Cambridge,

Butler, Judith Mass.: Harvard University Press.

2004 Precarious Life: The Powers of Mourning and Violence. London: Verso.

Crosson, J. Brent

2017 "Catching Power: Problems with Possession, Sovereignty, and African Religions in Trinidad.” Ethnos 84, no. 4: 588-614. https://doi.org/10.1080/00141844.2017. 1412339 .

Cunha, Olívia Gomes da

2018 "Introduction: Exploring Maroon Worlds on the Move." In Maroon Cosmopolitics: Personhood, Creativity and Incorporation, edited by Olívia Maria Gomes da Cunha, 1-32. Leiden: Brill.

Dave, Naisargi N.

2014 "Witness: Humans, Animals, and the Politics of Becoming." Cultural Anthropology 29, no. 3: 433-56. https://doi.org/10.14506/ca29.3.01.

Derrida, Jacques

1994 Specters of Marx. London: Routledge.

2008 The Animal That Therefore I Am. Edited by Marie-Louise Mallet. Translated by David Wills. New York: Fordham University Press. 
Descola, Phillippe

1996 In the Society of Nature: A Native Ecology in Amazonia. Cambridge, UK: Cambridge University Press.

Espírito Santo, Diana

2015 Developing the Dead: Mediumship and Selfhood in Cuban Espiritismo. Gainesville: University Press of Florida.

Evans-Pritchard, E. E.

1937 Witchcraft, Oracles and Magic Among the Azande. Oxford: Clarendon Press.

Fassin, Didier

2008 "The Humanitarian Politics of Testimony: Subjectification through Trauma in the Israeli-Palestinian Conflict." Cultural Anthropology 23, no. 3: 531-58. https://doi.

Foucault, Michel org/10.1111/j.1548-1360.2008.00017.x.

1977 Discipline and Punish: The Birth of the Prison. New York: Random House.

Freud, Sigmund

1957 "Mourning and Melancholia." In The Standard Edition of the Complete Psychological Works of Sigmund Freud Volume XIV, (1914-1916), 237-58. London: Hogarth and Institute of Psycho-Analysis.

García, María Elena

2019 "Death of a Guinea Pig: Grief and the Limits of Multispecies Ethnography in Peru." Environmental Humanities 11, no. 2: 351-72. https://doi.org/10.1215/220119197754512 .

Govindrajan, Radhika

2017 Animal Intimacies: Interspecies Relatedness in India's Central Himalayas. Chicago: University of Chicago Press.

Gruen, Lori

2014 Entangled Empathy: An Alternative Ethic for Our Relationships with Animals. New York: Lantern.

Hallowell, A. Irving

1960 Ojibwa Ontology, Behavior, and World View. New York: Columbia University Press. Haraway, Donna J.

2007 When Species Meet. Minneapolis: University of Minnesota Press.

Hertz, Robert

1960 Death and the Right Hand. London: Cohen and West.

Keane, Webb

2014 Ethical Life: Its Natural and Social Histories. Princeton, N.J.: Princeton University Press.

Kim, Claire Jean

2015 Dangerous Crossings: Race, Species, and Nature in a Multicultural Age. Cambridge,

King, Barbara J.

UK: Cambridge University Press.

2014 How Animals Grieve. Chicago: University of Chicago Press.

Kirksey, Eben

2015 Emergent Ecologies. Durham, N.C.: Duke University Press.

Lambek, Michael

1981 Human Spirits: A Cultural Account of Trance in Mayotte. Cambridge: Cambridge University Press.

Mackenzie, Catriona

2008 "Relational Autonomy, Normative Authority and Perfectionism." Journal of Social Mbembe, Achille Philosophy 39, no. 4: 512-33. https://doi.org/10.1111/j.1467-9833.2008.00440.x.

2003 “Necropolitics." Translated by Libby Meintjes. Public Culture 15, no. 1: 11-40. https://doi.org/10.1215/08992363-15-1-11. 
Moomou, Jean

2004 Le Monde des Marrons du Maroni en Guyane (1772-1860): La naissance d'un peuple: Les Boni. Matoury: Ibis Rouges Editions.

Mueggler, Erik

2017 Songs for Dead Parents: Corpse, Text, and World in Southwest China. Chicago: University of Chicago Press.

Parreñas, Juno Salazar

2018 Decolonizing Extinction: The Work of Care in Orangutan Rehabilitation. Durham, N.C.: Duke University Press.

Parris, Jean-Yves.

2011 Interroger les morts: Essai sur la dynamique politique des Noirs marrons Ndjuka du Surinam et de la Guyane. Matoury: Ibis Rouges Editions.

Pires, Rogério Brittes W.

2019 “Funerals, Rhetorics, Rules and Rulers in Upper Suriname." In Maroon Cosmopolitics: Personhood, Creativity and Incorporation, edited by Olívia Maria Gomes da Cunha, 234-67. Leiden: Brill.

Plumwood, Val

2012 Eye of the Crocodile. Edited by Lorraine Shannon. Canberra: Australian National University Press.

Price, Richard

1973 “Avenging Spirits and the Structure of Saramaka Lineages." Bijdragen tot de Taal-, Land-, en Volkekunde 129: 86-107. https://doi.org/10.1163/22134379-90002733.

Rilke, Rainer Maria

2000 Duino Elegies. Translated by Gary Miranda. New York: North Point Press.

Rosaldo, Renato

1993 Culture and Truth: The Remaking of Social Analysis. Boston: Beacon.

Sahlins, Marshall

2013 What Kinship Is — And Is Not. Chicago: University of Chicago Press.

Strange, Stuart Earle

2016 "The Dialogical Collective: Mediumship, Pain, and the Interactive Creation of Ndyuka Maroon Subjectivity." Journal of the Royal Anthropological Institute 22, no. 3: 516-33. https://doi.org/10.1111/1467-9655.12444.

2018 “'It's your family that kills you': Responsibility, Evidence, and Misfortune in the Making of Ndyuka History." Comparative Studies in Society and History 60, no. 3: 629-58. https://doi.org/10.1017/S001041751800021X.

Strawson, Peter

1962 “Freedom and Resentment." Proceedings of the British Academy 48: 1-25.

Thoden van Velzen, H.U.E.

1966 "Het geloof in wraakgeesten; Bindmiddel en splijtzwam van de Djuka matrilineage." Nieuwe West-Indische Gids 45: 45-51. https://doi.org/10.1163/22134360-90002275.

Thoden van Velzen, H.U.E., and W. Hoogbergen

2011 Een zwarte vrijstaat in Suriname: De Okaanse samenleving in de 18E Eeeuw. Leiden: KITLV.

Thoden van Velzen, H.U.E., and Wilhelmina van Wetering

2004 In the Shadow of the Oracle: Religion as Politics in a Suriname Maroon Society. Long Grove, Ill.: Waveland Press.

Thomas, Keith

1983 Man and the Natural World: Changing Attitudes in England 1500-1800. London: Allen Lane.

Tsing, Anna Lowenhaupt

2012 "On Nonscalability: The Living World Is Not Amenable to Precision-Nested Scales." Common Knowledge 18, no. 3: 505-24. https://muse.jhu.edu/article/485828.

Turner, Victor

1981 The Drums of Affliction: A Study of Religious Processes among the Ndembu of Zambia. Ithaca: Cornell University Press. 
Van Dooren, Thom

2014 Flight Ways: Life and Loss at the Edge of Extinction. New York: Columbia University Press.

Viveiros de Castro, Eduardo

2012 Cosmological Perspectivism in Amazonia and Elsewhere. Chicago: Hau Books.

Weil, Kari

2012 Thinking Animals: Why Animal Studies Now? New York: Columbia University Press.

Wekker, Gloria

2006 The Politics of Passion: Women's Sexual Culture in the Afro-Surinamese Diaspora. New York: Columbia University Press.

Williams, Eric

1994 Capitalism and Slavery. Chapel Hill: University of North Carolina Press. Originally published in 1944.

Wirtz, Kristina

2018 "Mourning as Political Action: Hauntology and Ghost Chronotopes in the Americas." Paper presented at Yale-NUS College, March 12, 2018.

Wynter, Sylvia

1994 “No humans involved': An Open Letter to My Colleagues.” Forum N.H.I. 1, no. 1: $42-73$. 